\title{
HDAC2 wt Allele
}

National Cancer Institute

\section{Source}

National Cancer Institute. HDAC2 wt Allele. NCI Thesaurus. Code C49390.

Human HDAC2 wild-type allele is located within $6 q 21$ and is approximately $30 \mathrm{~kb}$ in length.

This allele, which encodes histone deacetylase 2 protein, is involved in both the deacetylation of lysine residues on the $\mathrm{N}$-terminal region of the core histones $(\mathrm{H} 2 \mathrm{~A}$, $\mathrm{H} 2 \mathrm{~B}, \mathrm{H} 3$ and $\mathrm{H} 4$ ) and the formation of transcriptional repressor complexes. Reduced expression of the HDAC2 gene is associated with chronic obstructive pulmonary disease. 